\title{
TINJAUAN HUKUM DAN KEBIJAKAN KAWASAN KONSERVASI LAUT (KKL) MUKIM IE MEULEE, KOTA SABANG: Suatu Implementasi Pengelolaan Perikanan Tangkap di Pulau Kecil
}

\section{Policy Review on Marine Protected Area Management in Ie Meulee Subdistrict, Sabang District: Capture Fisheries Management Implementation in Small Island}

\author{
Oleh:
}

\author{
Irfan Yulianto ${ }^{*}$, Budy Wiryawan², Ahmad Mukminin ${ }^{1}$ \\ 1 Wildife Conservation Society Indonesia Program \\ 2 Departemen Pemanfaatan Sumber Daya Perikanan, FPIK, IPB \\ ${ }^{*}$ Korespondensi: irfanyulianto@yahoo.com
}

Diterima: 11 Oktober 2010; Disetujui: 28 Januari 2011

\begin{abstract}
The coastal area of Weh Island is divided into sub-districts (Ihok) which are managed by traditional leader known as Panglima Laot. The Panglima Laot has the authority to regulate customary laws that aimed to bring social harmony and resolve conflicts concerning the marine resource use. In Anoi Itam and le Meulee of the east coast of Weh Island, the communities have high awareness toward the sustainable of the natural resources use, and this has led to the implementation of gear restrictions and no fishing zones regulations as part of their customary laws. These regulations have generated conflict with the other custom community, because the other custom community claimed that these existing customary regulations do not have legal base regulations. Gap analysis and analytical hierarchy process was used to analyze and describe the regulation that can be used as their optional regulation base. The result indicated that the Weh Island custom community had chosen a marine protected area that managed by community through Panglima Laot adopting regulations that recognised by local government. In the process of implementation, the determination area is a key priority (36.92\%) followed by the establishment of management institutions (23.92\%), financing (21.19\%) and surveillance (17.94\%).
\end{abstract}

Key words: Gap Analysis, Hierarchy Process Analysis, Marine Protected Area

\section{ABSTRAK}

Pantai timur Pulau Weh, Kota Sabang, Provinsi Aceh secara adat terdapat dua Panglima Laot yang memiliki kewenangan yaitu Panglima Laot le Meulee dan Anoi Itam (Mukim le Meulee). Nelayan di kedua wilayah panglima laot tersebut telah memiliki beberapa aturan adat dalam mengelola wilayah pesisir mereka seperti pelarangan penggunaan jaring yang menurut nelayan merusak sumber daya mereka. Namun, tidak semua nelayan di Kota Sabang mentaati aturanaturan tersebut. Nelayan di luar wilayah tersebut menganggap aturan adat nelayan le Meulee tidak punya dasar hukum baik hukum normatif ataupun hukum agama. Metode gap analisis dan Analisis Hierarkhi Proses digunakan untuk menggambarkan dan menganalisa aturan-aturan yang dapat menjadi dasar bagi para nelayan memberlakukan aturan yang mereka inginkan. Selain itu Analisis Hierarkhi Proses juga untuk menentukan opsi-opsi dalam implementasi aturan nelayan. Berdasarkan hasil analisis hirarki proses menunjukkan pihak di Pulau Weh memilih bentuk kawasan konservasi yang dikelola oleh adat (panglima laot) dengan pengaturan alat tangkap. Namun para pihak memilih aktor utama dalam pengembangan kawasan konservasi adalah Pemerintah Kota Sabang. Dalam proses implementasi, penetapan kawasan merupakan prioritas 
utama (36,92\%) yang kemudian diikuti oleh pembentukan lembaga pengelola $(23,92 \%)$, pencarian pendanaan (21,19\%) dan pengawasan (17,94\%).

Kata kunci: Gap Analisis, Analisis Hierarkhi Proses, Kawasan Konservasi Laut

\section{PENDAHULUAN}

\section{Latar Belakang}

Pantai timur Pulau Weh, Kota Sabang, Nangroe Aceh Darussalam secara administrasi terdiri dari tiga kelurahan yaitu Kelurahan le Meulee, Ujung Kareung, dan Anoi Itam. Selain itu secara adat terdapat dua Panglima Laot yang memiliki kewenangan yaitu Panglima Laot le Meulee dan Anoi Itam (Mukim le Meulee). Nelayan di kedua wilayah panglima laot tersebut telah memiliki beberapa aturan adat dalam mengelola wilayah pesisir mereka seperti pelarangan penggunaan jaring dan beberapa alat tangkap yang menurut nelayan merusak sumber daya mereka serta penetapan beberapa wilayah menjadi zona larang ambil. Pengaturan tersebut menunjukkan masyarakat di dua wilayah panglima laot tersebut telah mengembangkan suatu kawasan konservasi.

Namun, tidak semua nelayan di Kota Sabang mentaati aturan-aturan yang telah ditetapkan oleh nelayan wilayah adat le Meulee dan
Anoi Itam. Nelayan di luar wilayah tersebut menganggap aturan adat nelayan le Meulee tidak punya dasar hukum baik hukum formal ataupun hukum agama, dalam hal ini Agama Islam, sehingga sering terjadi konflik horisontal. Melihat hal ini masyakat di dua wilayah panglima laot tersebut berkoordinasi dengan pemerintah untuk mengembangkan kawasan konservasi laut secara formal. Untuk itu diperlukan sebuah tinjauan hukum dan kebijakan mengenai kawasan konservasi laut di wilayah Mukim le Meulee.

\section{Tujuan}

Tujuan dari pembuatan penelitian ini adalah memberikan gambaran tentang opsi yang dapat dilakukan dalam pengembangan kawasan konservasi laut atau kawasan kelola laut berdasarkan peraturan yang berlaku dan menganalisa opsi-opsi yang ada dengan metode analisis proses hirarki, sehingga opsi-opsi yang dipilih sesuai dengan keinginan para pihak di Pulau Weh.

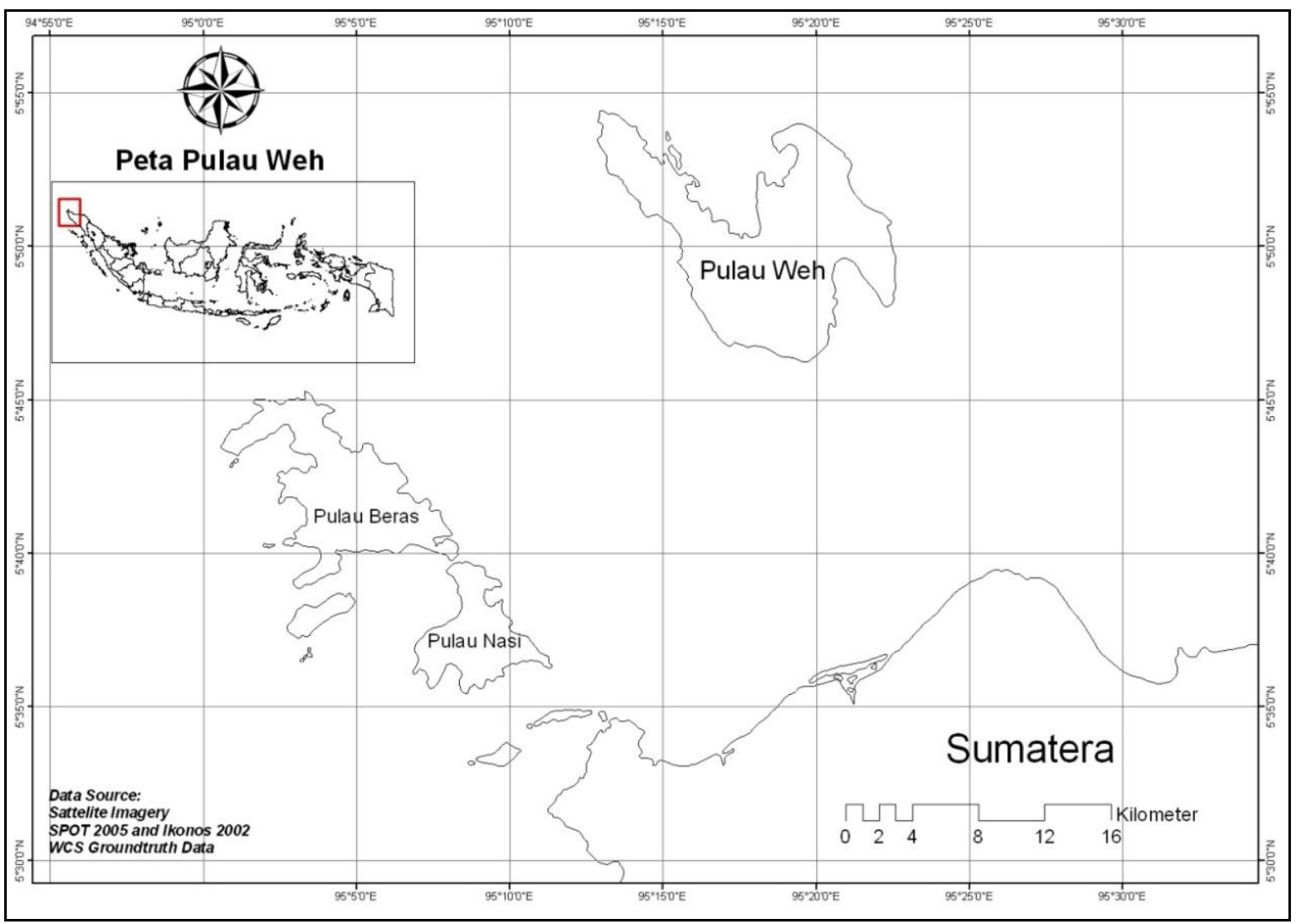

Gambar 1 Peta Lokasi Penelitian. 


\section{METODE PENELITIAN}

\section{Bahan Analisis}

Banyaknya undang-undang yang mengatur tentang kawasan konservasi laut di Indonesia membuat berbagai pihak memiliki opsi-opsi alternatif dalam mengembangkan kawasan konservasi baik dari segi status, bentuk, dasar hukum ataupun lembaga pengelola. Selain itu pemberian otonomi khusus pada beberapa wilayah di Indonesia seperti Nangroe Aceh Darussalam menambah warna tersendiri dalam menerapkan pengelolaan sumber daya pesisir serta landasan hukumnya.

Beberapa peraturan perundang-undangan yang berkaitan dengan pengelolaan kawasan konservasi baik dalam hal penetapan ataupun pengelolaan suatu kawasan di Nangroe Aceh Darussalam adalah:

1. UU Nomor 5 Tahun 1990 tentang Konservasi Sumber daya Alam Hayati dan Ekosistemnya (KSDHA\&E).

2. UU Nomor 23 Tahun 1997, tentang PengeIolaan Lingkungan Hidup.

3. UU Nomor 41 Tahun 1999, tentang Kehutanan sebagaimana telah diubah dengan Undang-Undang Nomor 19 Tahun 2004.

4. UU Nomor 31 Tahun 2004 tentang Perikanan.

5. UU Nomor 32 Tahun 2004 tentang Pemerintahan Daerah.

6. UU Nomor 11 Tahun 2006 tentang Pemerintahan Aceh.

7. UU Nomor 26 Tahun 2007, tentang Penataan Ruang.

8. UU Nomor 27 Tahun 2007 tentang PengeloIaan Wilayah Pesisir dan Pulau-Pulau Kecil.

9. Peraturan Pemerintah Republik Indonesia Nomor 68 Tahun 1998 tentang Kawasan Suaka Alam dan Pelestarian Alam

10.Peraturan Pemerintah Republik Indonesia Nomor 38 Tahun 2007, tentang Pembagian Urusan Pemerintahan Antara Pemerintah, Pemerintahan Daerah Provinsi, Pemerintahan Daerah Kabupaten/Kota

11.Peraturan Pemerintah Republik Indonesia Nomor 60 Tahun 2007, tentang Konservasi Sumber daya Ikan

12.Keputusan Menteri Pertanian Nomor 392/ Kpts/IK.120/4/99 tentang Jalur-Jalur Penangkapan Ikan

Selain beberapa undang-undang di atas terdapat beberapa Qanun Pemerintahan Propinsi Nangroe Aceh Darussalam dan sumber lain sebagai bahan analisis seperti:

1. Qanun Provinsi Nangroe Aceh Darussalam Nomor 16 Tahun 2002 tentang Pengelolaan Sumber daya Kelautan dan Perikanan.

2. Qanun Provinsi Nangroe Aceh Darussalam
Nomor 20 Tahun 2002 tentang Konservasi Sumber daya Alam.

3. Qanun Provinsi Nangroe Aceh Darussalam Nomor 4 Tahun 2003 tentang Pemerintahan Mukim dalam Provinsi Nangroe Aceh Darussalam.

4. Qanun Provinsi Nangroe Aceh Darussalam Nomor 5 Tahun 2003 tentang Pemerintahan Gampong dalam Provinsi Nanggroe Aceh Darussalam.

5. Hukum Adat Laut Sabang

\section{Analisis Hirarki Proses}

Analisis proses hirarki merupakan suatu teknik analisis terstruktur untuk pengambilan keputusan yang sangat kompleks. Teknik ini berdasarkan perhitungan matematis dan psikologi responden dikembangkan pertama kali oleh Saaty pada tahun 1980 . Teknik AHP memberikan framework yang rasional dan komprehensif dalam menyusun struktur masalah, mengukur dan menghubungkan elemen-elemen untuk capaian dalam pengambilan keputusan dan menentukan solusi alternatif. Dalam penelitian ini struktur AHP dalam penelitian ini terdiri dari 3 level yaitu; level 1:goal yang merupakan pemilihan jenis kawasan konservasi yang sesuai di wilayah Mukim le Meulee, level 2: tahapan yang merupakan tahapan yang perlu dilakukan untuk pengembangan kawasan konservasi, dan level 3: aktor yang merupakan aktor-aktor yang akan berperan dalam pengembangan dan pengelolaan kawasan konservasi.

Alternatif dalam pengembangan kawasan konservasi adalah Daerah Pelindungan Laut (DPL), Kawasan Konservasi Laut Adat (KKL Adat), dan Kawasan Konservasi Laut Daerah. DPL adalah kawasan konservasi berbasis masyarakat dimana seluruh pengelolaan dan pengaturannya dilakukan oleh masyarakat. Luas DPL umumnya relatif kecil yang terdiri dari zona inti dan zona penyangga. KKL Adat adalah kawasan konservasi yang dikelola bersama antar pemerintah dan masyarakat, khususnya masyarakat adat. Masyarakat adat memiliki peranan utama dalam pengaturan kawasan tersebut. KKLD adalah kawasan konservasi yang berbasis pemerintah dimana kawasan tersebut ditetapkan, dikelola dan diatur oleh pemerintah. Berdasar gambaran opsi-opsi yang dapat dilakukan dalam pengembangan kawasan konservasi laut atau kawasan kelola laut maka disusun struktur masalah seperti yang ditampilkan pada Gambar 2.

Setiap elemen dari suatu level/tingkat akan diperbandingkan secara berpasangan. Penentuan seberapa besar pentingnya suatu 
elemen terhadap elemen lainnya digunakan skala perbandingan dari Saaty (1990) (Tabel 1).

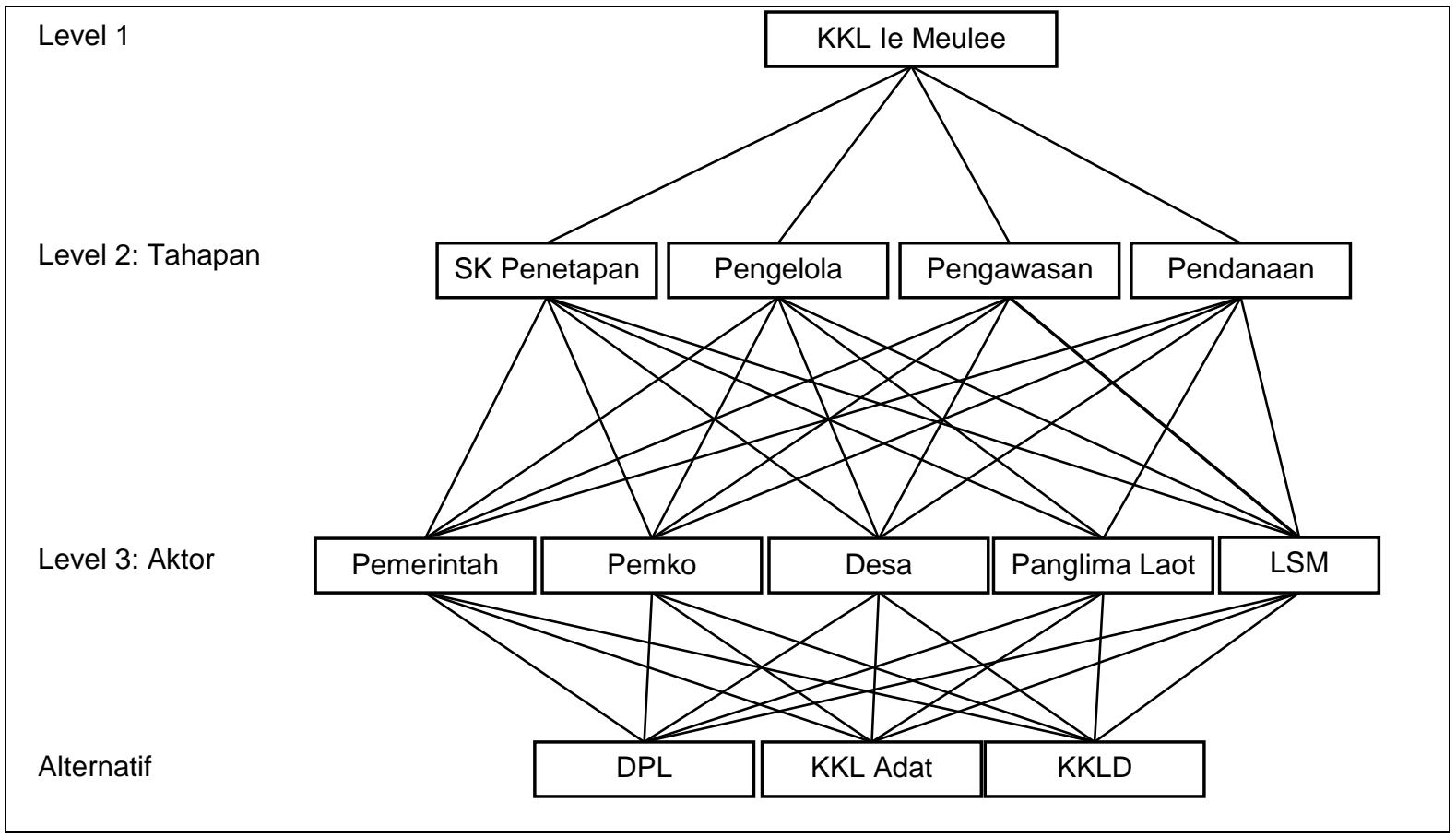

Gambar 2 Struktur AHP.

Tabel 1 Penilaian Skala Berpasangan.

\begin{tabular}{cl}
\hline Nilai & \multicolumn{1}{c}{ Definisi } \\
\hline 1 & Kedua faktor sama pentingnya \\
3 & Faktor yang satu sedikit lebih penting dari faktor lainya \\
5 & Faktor satu esensial atau lebih penting dari faktor lainnya \\
7 & Satu faktor jelas lebih penting dari faktor lainnya \\
9 & Satu faktor mutlak lebih penting dari pada faktor lainnya \\
$2,4,6,8$ & Nilai-nilai antara \\
\hline
\end{tabular}

Responden pengisian nilai setiap elemen adalah 9 orang berasal staf dinas perikanan Kota Sabang, Bapeda Kota Sabang, Bapedalda Kota Sabang, Panglima Laot, Tokoh Masyarakat, dan Staf LSM.

\section{HASIL DAN PEMBAHASAN}

\section{Opsi-opsi Dasar Hukum dan Penetapan}

Dalam sistem hukum Indonesia, opsi-opsi dasar hukum dana penetapan pengembangan kawasan konservasi laut di wilayah pantai barat berdasarkan 3 tinjauan yaitu Hukum Islam, Hukum Adat dan Hukum Negara.

\section{Hukum/Syariat Islam}

Tinjauan aspek hukum di NAD tidak dapat dilepaskan dari tinjauan aspek Syariat Islam. Hal ini dikarenakan sebagian besar hu- kum adat di NAD mengadopsi Syariat Islam. Mengutip beberapa tulisan Fachruddin M. Mangunjaya bahwa Hukum syariat Islam mempunyai bentuk-bentuk dasar dan semangat konservasi alam yang baik sebagai referensi. Hal ini bisa dilihat dari beberapa ayat dalam AlQur'an:

Dan janganlah kamu mentaati perintah orangorang yang melewati batas, yang membuat kerusakan di muka bumi dan tidak mengadakan perbaikan (Q.S. Asy-Su'araa, 26: 151-152).

Dan janganlah kamu membuat kerusakan di muka bumi, sesudah (Allah) memperbaikinya dan berdoalah kepada-Nya dengan rasa takut (Tidak akan diterima) dan harapan (akan dikabulkan). Sesungguhnya rahmat Allah amat dekat kepada orang-orang yang berbuat baik (Q.S. Al-A'raf, 7:56). 
Kedua ayat tersebut di atas menunjukkan bahwa Hukum Islam juga mengatur untuk tidak merusak alam yang berarti mewajibkan umat Islam untuk menjaga/memelihara sumber daya alam salah satunya adalah sumber daya pesisir.

Selain ayat dalam Al Qur'an, Nabi Muhammad SAW juga mengajarkan sistem kawasan lindung yang disebut dengan Hima. Hima merupakan suatu kawasan khusus yang dilindungi oleh pemerintah (imam ataupun khalifah) atas dasar syariat melestarikan kehidupan liar dan sumber daya alam.

Di Indonesia Hima dapat bermakna: taman nasional, hutan lindung, suaka margasatwa, kawasan konservasi laut, daerah perlindungan laut. Hima merupakan kawasan lindung yang di buat oleh Rasullullah SAW yang diakui oleh FAO sebagai contoh pengelolaan kawasan lindung paling tua bertahan di dunia.

Oleh karena itu, sebagai legitimasi syariah, misalnya, untuk menjadikan penekanan 'Islami' terhadap kawasan konservasi, maka adalah absah untuk memberikan nama baru yang Islami. Nangroe Aceh Darussalam (NAD) yang telah ber'azam menerapkan syariat Islam, memiliki potensi yang kuat untuk menerapkan baik secara istilah, maupun praktis dari syariat hima' ini.

\section{Hukum Adat}

Sistem hukum Indonesia mengakui keberadaan dan keberlakuan hukum adat pada seluruh wilayah ulayat yang ada di Indonesia, namun pelaksanaannya sering kali hukum adat tersebut sudah dimodifikasi dalam hukum nasional ataupun sulit dilaksanakan karena tidak ada keinginan yang kuat dari pemerintah untuk mengakuinya.

Menurut Witanto (2006) disebutkan bahwa di beberapa wilayah panglima laot di Kota Sabang memiliki aturan adat tentang larangan bentuk penangkapan ikan. Hukum adat laot yang berlaku di wilayah sabang antara lain, yaitu; (1) Larangan untuk menangkap ikan dengan menggunakan zat peledak atau zat kimia yang secara keras diberlakukan di wilayah Anoi Itam, Ujung Kareung dan le Meulee, (2) Larangan untuk menangkap ikan menggunakan Pukat Harimau yang diberlakukan hampir di seluruh wilayah Sabang, (3) Larangan untuk menangkap ikan dengan menggunakan segala bentuk jaring yang diberlakukan di wilayah panglima laot Iboih, Anoi Itam dan le Meulee, (4) Larangan melakukan penangkapan terhadap ikan hias yang diberlakukan di wilayah panglima laot lboih dan kemudian dikuatkan dengan Peraturan Daerah Kota Sabang nomor 6
Tahun 1997, (5) Larangan untuk melakukan penangkapan terhadap satwa laut yang dilindungi.

Hukum adat laot yang berlaku di wilayah panglima laot Anoi Itam dan le Meulee (Mukim le Meulee) menunjukkan adanya mekanisme pengaturan alat tangkap untuk kelestarian sumber daya alam. Pengaturan alat tangkap tersebut merupakan bagian dari sistem kawasan konservasi laut. Kehadiran hukum adat disamping hukum negara merupakan suatu kenyataan bahwa sejak lama masyarakat adat di wilayah mukim le Meulee telah mengatur pemanfaatan sumber daya perikanan mereka.

\section{Hukum Negara}

Sebelum tahun 2004 penetapan dan pengelolaan kawasan konservasi didasarkan kepada UU No 5 Tahun 1990 tentang KSDAH\& E dan No 24 Tahun 1992 tentang Tata Ruang UU serta peraturan pemerintah turunannya seperti PP No 68 Tahun 1999 tentang Kawasan Suaka Alam dan Pelestarian Alam (Patlis et al. 2004). Berubahnya paradigma tentang otonomi daerah dengan dikeluarkannya UU No 32 Tahun 2004 tentang Pemerintah Daerah dan ditetapkannya UU No 31 Tahun 2004 tentang Perikanan membuat berbagai pihak merasa perlu meninjau mekanisme pengelolaan kawasan konservasi khususnya kawasan konservasi laut. Selain itu dengan direvisinya UU No 24 Tahun 1992 menjadi UU No 26 Tahun 2007 tentang Tata Ruang dan diterbitkannya UU No 27 Tahun 2007 tentang Pengelolaan Wilayah Pesisir dan PulauPulau Kecil semakin memberi ruang bagi berbagai pihak untuk melakukan perubahan sistem pengelolaan kawasan konservasi laut.

Namun cukup disayangkan sampai saat ini belum dikeluarkannya peraturan pemerintah yang secara teknis mengatur tentang penetapan dan pengelolaan kawasan konservasi laut. Hal ini membuat para pihak melakukan penafsiran analogis dari berbagai undang-undang dan peraturan pemerintah dalam menetapkan dan menentukan sistem pengelolaan kawasan konservasi laut (Wiryawan et al. 2005), walaupun mekanisme penetapan Kawasan Konservasi di Wilayah Pesisir telah ditetapkan dengan Peraturan Pemerintah No. 60 Tahun 2007 dan PER. 17/MEN/2008.

Pembelajaran analisis kebijakan dan hukum Kawasan Konservasi Laut Berau menunjukkan bahwa landasan hukum dalam mengembangkan suatu KKL dapat didasarkan pada UU No. 31/2004 atau. UU No. 5/1990 dan berkaitan dengan UU No. 32/2004 dimana penetapan KKL dapat dilakukan oleh Menteri Kelautan dan Perikanan, Pemerintah Propinsi ataupun Pemerintah Kabupaten tergantung batas KKL yang 
dikembangkan (Wiryawan dan Dermawan 2007).

Selain itu UU No. 27/2007 pada Bagian Ketiga tentang Konservasi pasal 28 angka 3 menunjukkan kawasan yang diatur dengan adat tertentu dimana disebutkan salah satunya aturan panglima laot dapat dijadikan kawasan konservasi. Undang-undang dan peraturan dari pemerintah pusat tersebut memiliki peranan penting dalam pengembangan kawasan konservasi di daerah. Hal ini juga disampaikan oleh Pameroy dan Berkes (1997) dan Pameroy dan Carlos (1997) dimana pada pembelajaran pengembangan kawasan konservasi di Filipina undang-undang pemerintah pusat memberi peranan penting bagi keberhasilan kawasan konservasi dari segi pengelolaannya.

Selain uraian tersebut diatas secara eksplisit UU No 11. Tahun 2006 tentang Pemerintahan Aceh pada pasal 142 menyebutkan bahwa dalam perencanaan, pengaturan, penetapan dan pemanfaatan tata ruang kabupaten/kota harus mempertimbangkan: (1) Adat budaya setempat; (2) Penyediaan tanah untuk fasilitas sosial dan umum, jaringan prasarana jalan, pengairan,dan utilitas; (3) Keberpihakan kepada masyarakat miskin; (4) Daerah-daerah rawan bencana; (5) Penyediaan kawasan lindung dan ruang terbuka hijau serta untuk pelestarian taman nasional; (6) Pemberian insentif dan disinsentif; (7) Pemberian sanksi; dan (8) Pengendalian pemanfaatan ruang.

Pasal 148, 149, serta pasal 163 secara eksplisit pemerintah aceh, kabupaten/kota memiliki kewenangan mengelolaan sumber daya kelautan dan perikanan dimana salah satunya meliputi konservasi dan pengelolaan sumber daya alam pesisir. Berdasarkan UU No.11/ 2006 tersebut menegaskan bahwa pemerintah Kota Sabang memiliki kewenangan dan hak dalam pengelolaan lingkungan hidup secara terpadu yang dalam pengembangannya diwajibkan melibatkan adat istiadat setempat dan masyarakat memiliki hak untuk terlibat dalam pengelolaan lingkungan hidup.

Pada lingkup yang lebih kecil; yaitu Gampong (pemerintah setingkat desa), menurut Qonun nomor 5 tahun 2003 Propinsi NAD, Gampong dapat menerbitkan Reusam atau peraturan-peraturan yang diterbitkan Gampong. Hal ini juga memberi peluang kepada masyarakat dalam sebuah gampong menerbitkan aturan pemanfaatan sumber daya pesisir yang mekanismenya disepakti bersama.

Syariat Islam, hukum adat dan hukum negara telah memberi peluang kepada masyarakat di wilayah mukim le Meulee untuk membentuk sebuah kawasan konservasi laut dalam kerangka melestarikan wilayah pesisir mereka dari alat tangkap yang merusak dan pengambilan berlebih. Berbagai opsi dalam pembentukan kawasan konservasi laut di Kota Sabang khususnya di Mukim le Meulee sebagai berikut: (1) Kawasan konservasi dapat dibentuk di masing-masing wilayah adat lhok Anoi Itam dan le Meulee dengan dasar hukum keputusan Panglima Laot yang berisi batas dan aturan; (2) Kawasan konsevasi laut dapat dibentuk di masingmasing gampong dengan dasar hukum berupa reusam yang berisi batas, lembaga pengelola dan aturan-aturan dalam wilayah tersebut; (3) Kawasan konservasi laut dapat dibentuk di tingkat mukim, dengan dasar hukum SK Walikota Sabang yang berisi batas lembaga pengelola dan aturan-aturan.

\section{Opsi-opsi pengaturan}

Secara umum nelayan wilayah Lhok Anoi Itam dan Lhok le Meulee menginginkan adanya pengaturan penggunaan alat tangkap khususnya jaring di wilayah lhok tersebut. Nelayan sadar bahwa dengan menggunakan jaring maka sumber daya perikanan yang dimiliki akan habis sehingga para nelayan tidak dapat mencari makan lagi. Selain itu nelayan di wilayah Ihok Anoi Itam telah menentukan beberapa wilayah untuk dijadikan daerah larang ambil (zona inti) atau daerah perlindungan laut.

Aturan pembatasan alat tangkap jaring (dalam hal ini alat tangkap jaring yang telah dimodifikasi/modern) telah sejalan dengan beberapa aturan yang dikeluarkan oleh pemerintah. Aturan teknis yang mengatur tentang pelarangan penggunaan alat tangkap modern di wilayah terumbu karang adalah SK menteri pertanian nomor 392/Kpts/IK.120/4/99 tentang Jalur-jalur Alat Tangkap. SK tersebut menyebutkan bahwa alat tangkap yang boleh beroperasi di wilayah terumbu karang (0-3 mil laut) adalah alat tangkap tradisional yang belum di modifikasi dan menggunakan mesin perahu di bawah $5 \mathrm{GT}$. Hal ini jelas bahwa alat tangkap jaring yang telah di modifikasi hanya boleh beroperasi di atas 3 mil laut. Selain keputusan menteri tersebut, Qanun Provinsi NAD nomor 20 tahun 2002 pada pasal 18 menyebutkan tentang ketentuan konservasi sumber daya alam di bidang kelautan dan perikanan meliputi: (1) Alat tangkap dan tata cara penangkapan ikan; (2) Jumlah, jenis serta ukuran ikan yang boleh ditangkap; (3) Daerah, jalur dan waktu atau musim penangkapan; (4) Pencegahan pencemaran dan kerusakan, rehabilitasi dan peningkatan sumber daya ikan serta lingkungan; (5) Penebaran ikan jenis baru atau eksotik; (6) Pencegahan dan pemberantasan hama dan penyakir ikan yang ditetapkan lebih lanjut dalam kepu- 
tusan gubernur. Berdasarkan qonun tersebut sangat jelas bahwa Pemerintah Provinsi NAD juga mengatur tentang pengaturan alat tangkap.

Aturan penentuan daerah larang ambil telah sejalan dengan beberapa peraturan mulai dari Undang-undang sampai dengan qonun di provinsi NAD dimana masyarakat dapat menentukan daerah larangan ambil dengan beberapa pertimbangan kelestarian. Dasar pertimbanganya adalah setiap peraturan yang mengatur tentang pengembangan kawasan konservasi laut baik dalam undang-undang, peraturan pemerintah, surat keputusan menteri ataupun qanun mencantumkan tentang peran serta masyarakat dalam kegiatan konservasi yang memberikan ruang pada masyarakat untuk terlibat dalam kegiatan konservasi dimana salah satu bentuknya adalah pembuatan kawasan larang ambil. Pengaturan-pengaturan dalam kawasan konservasi yang dilakukan oleh masyarakat sangat penting bagi keberhasilan kawasan konservasi tersebut. Christie et al. (2002) menyebutkan bahwa jika kawasan konservasi tidak diatur oleh masyarakat maka kawasan konservasi tersebut berpeluang akan gagal.

\section{Opsi-opsi Kelembagaan}

Berbagai opsi kelembagaan dapat digunakan sebagai dasar pertimbangan dalam memutuskan badan pengelola kawasan konserva- si yang telah dibentuk. Berdasarkan beberapa pembelajaran di beberapa tempat di Indonesia dan peraturan yang berlaku di Provinsi NAD: (1) Pengelola merupakan panglima laot di masing-masing lhok atau lembaga yang ditun-juk oleh panglima laot; (2) Pengelola dibentuk di masing-masing gampong berdasarkan keputusan kheucik dimana ditingkat mukim dibentuk forum koordinatif lembaga pengelola; (3) Pengelola merupakan UPT dari Dinas Kelautan dan Perikanan Kota Sabang, jika kawasan konservasi yang dibentuk berdasarkan SK Walikota; (4) Pengelola merupakan lembaga setingkat badan (Badan Layanan Umum) dibawah Walikota Sabang, jika kawasan konservasi yang dibentuk berdasarkan SK Walikota.

\section{Analisis Proses Hirarki}

Setelah dilakukan penilaian oleh para pihak yang berasal dari staf Badan Perencanaan Daerah (Bapeda) Kota Sabang, Badan Pengendalian Dampak Lingkungan (Bappedal) Kota Sa-bang, Dinas Kelautan dan Perikanan (DKP) Ko-ta Sabang, Imam Mukim le Meulee, Lurah le Meulee, Panglima Laut Lhok le Meulee dan Anoi Itam dan staf Yayasan Pugar menunjukkan bentuk alternatif kawasan konservasi laut yang menjadi pilihan adalah KKL Adat $(43,69$ $\%)$, kemudian DPL $(34,16 \%)$ dan pilihan terakhir adalah bentuk KKLD (22,15\%). KKL Adat yang menjadi pilihan utama para responden menunjukkan bahwa responden menginginkan $\mathrm{KKL}$ yang ada di wilayah le Meulee merupakan 


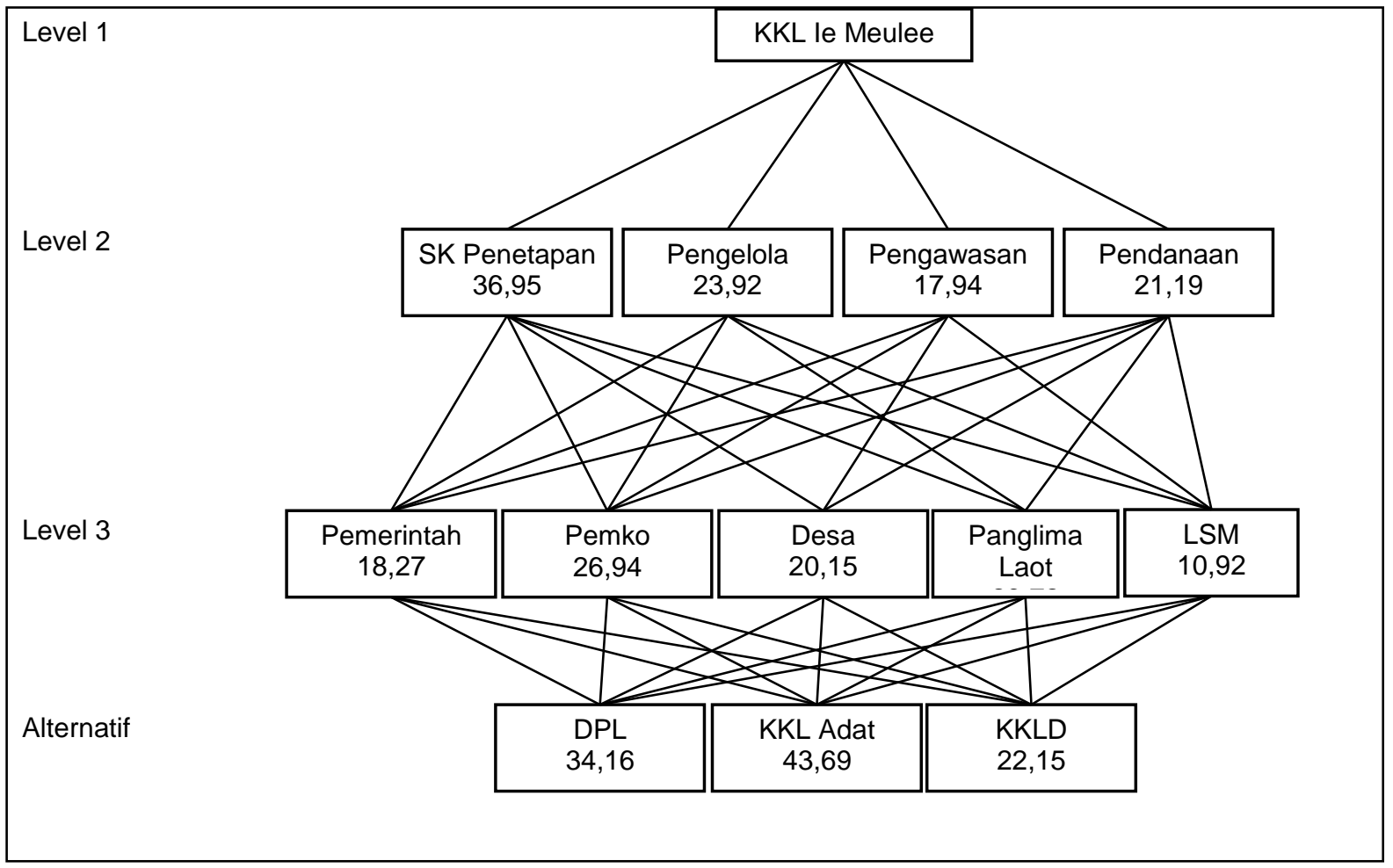

Gambar 3 Hasil Penilaian Para Pihak.

kawasan konservasi yang dikelola dan diatur oleh masyarakat adat yang ada di Mukim le Meulee. Para responden merasa jika kawasan konservasi tersebut dikelola oleh masyarakat adat kawasan tersebut akan lebih efektif dan berkelanjutan. McClanahan et al. (2006) menyampaikan bahwa kawasan konservasi yang dikelola oleh masyarakat adat dan masyarakat setempat relatif lebih berfungsi dibandingkan kawasan konservasi yang dikelola oleh pemerintah.

Hasil penilaian terhadap aktor menunjukkan Pemerintah Kota Sabang yang diharapkan paling berperan dalam pengembangan kawasan konservasi laut tersebut yaitu sebanyak $26,94 \%$, kemudian panglima laot sebanyak $23,72 \%$, gampong/kelurahan $20,15 \%$, pemerintah pusat $18,24 \%$ dan LSM sebanyak $10,92 \%$. Penilaian terhadap aktor yang berperan menunjukkan hal yang sedikit berbeda dengan alternatif bentuk kawasan. Hal ini menunjukkan bahwa meskipun kawasan konservasi dikelola oleh lembaga adat, namun masih diperlukan peranan pemerintah dalam pengelolaannya baik dari segi regulasi maupun pendanaanya. Pameroy dan Carlos (1997) menyebutkan perlu adanya pengelolaan bersama antara pemerintah dan masyarakat untuk lebih mengefektifkan kawasan konservasi. Lebih lanjut Pameroy dan Carlos (1997) menyebutkan pemerintah memiliki peran dalam hal regulasi untuk legalitas pengelolaan oleh masyarakat dan masyarakat khususnya masyarakat adat menjadi ujung tombak kegiatan pengelolaan.

Dalam proses pengembangan kawasan konservasi, menurut para pihak penetapan kawasan merupakan prioritas utama (36,92\%) yang kemudian diikuti oleh pembentukan lembaga pengelola $(23,92 \%)$, pencarian pendanaan $(21,19 \%)$ dan pengawasan sebanyak $(17,94$ $\%)$. Pentingnya dasar hukum penetapan kawasan konservasi telah disampaikan oleh Boersma and Parrish (1999), Pameroy dan Berkes (1997) dan Pameroy dan Carlos (1997) karena hal tersebut merupakan langkah awal legalitas pengembangan kawasan konservasi. Penetapan dasar hukum kawasan konservasi dilakukan oleh pemerintah, baik pemerintah pusat ataupun didelegasikan pada pemerintah daerah. Gambar diagram hasil penilaian para pihak ditampilkan pada Gambar 3.

\section{KESIMPULAN}

Terdapat beberapa opsi dalam pengembangan kawasan konservasi laut di Pulau Weh yaitu: (1) Dasar pembentukan kawasan konservasi laut dapat berdasarkan keputusan panglima laot, gampong atau Surat Keputusan Walikota dengan dasar UU No. 31/2004 tentang Perikanan, UU No. 32/2004 Tentang Pemerintahan Daerah, UU No. 11/ 2006 tentang Pemerintahan Aceh, dan UU No. 27/2007 tentang Pengelolaan Wilayah Pesisir dan Pulau-Pulau Kecil; (2) Aturan dalam kawasan konservasi 
laut antara lain pengembangan kawasan larang am-bil (DPL), pengaturan alat tangkap, dan pengembangan kawasan konservasi dengan beberapa zona dan aturan di masing-masing zona; (3) Opsi pengelola kawasan konservasi laut antara lain panglima laot, gampong, UPT di bawah Dinas Kelautan dan Perikanan Kota Sabang, atau lembaga setingkat badan (Badan Layanan Umum) dibawah Walikota Sabang.

Berdasarkan hasil analisis hirarki proses menunjukkan pihak di Pulau Weh memilih bentuk kawasan konservasi yang dikelola oleh adat (panglima laot) dengan pengaturan alat tangkap. Para pihak memilih aktor utama dalam pengembangan kawasan konservasi adalah $\mathrm{Pe}$ merintah Kota Sabang.

\section{DAFTAR PUSTAKA}

Boersma P.D. and J.K. Parrish. 1999. Limiting Abuse: Marine Protected Areas, a Limited Solution. Ecological Economics 31: 287-304

Christie P., A. White, \& E. Deguit. 2002. Starting Point or Solution? Community Based Marine Protected Areas in The Philippines. Journal of Environmental Management 66: 441-454

Mangunjaya F.M. 2007 Konservasi Alam dan Lingkungan Dalam Perspektif Islam. http://agamadanekologi.blog-spot.com/ 2007/03/konservasi-alamdan-lingkungandalam.html [26 No-vember 2007]

McClanahan T.R., M.J. Marnane, J.E. Cinner, \& W.E. Kiene 2006. A Comparison of Marine Protected Areas and Alternatif Approaches to Coral Reef Management. Current Biology 16: 1408-1413

Pameroy R.S. and F. Berkes. 1997. Two to Tanggo: The Role of Government in
Fisheries Co management. Marine Policy 21 (5):465-480.

Pameroy R.S. and M.B. Carlos. 1997. Community Based Coastal Resources Management in The Philipines: a Review and Evaluation of Program and Projects 1984-1994. Marine Policy 21 (5):445464

Patlis J.M., T.H. Purwaka, A. Wiyana, \& G.H. Perdanahardja (eds). 2005. Menuju Harmonisasi Sistem Hukum Sebagai Pilar Pengelolaan Wilayah Pesisir Indonesia. Seri Inisiatif Harmonisasi Sistem Hukum Pengelolaan Wilayah Pesisir Indonesia. Kementrian Perencanaan Pembangunan Nasional, Departemen Kelautan dan Perikanan, Departemen Hukum dab HAM bekerja sama dengan Coastal Resources Management Project II (USAID). Jakarta.

Saaty T.L. 1990. Multycriteria Decision Making: The Analitical Hierarchy Process. McGrow-Hill, Inc.

Wiryawan B., M. Khazali, \& M. Knight. 2005. Menuju Kawasan Konservasi Laut Berau, Kalimantan Timur: Status Sumber daya Pesisir dan Proses Pengembanganya. Program Bersama Kelautan Berau TNCWWF-Mitra Pesisir/ CRMP II USAID. Jakarta.

Wiryawan B. dan A. Dermawan. 2007. Panduan Pengembangan Kawasan Konservasi Laut Daerah/Marine Management Area (MMA) di Wilayah COREMAP II Indonesia Bagian Barat. COREMAP II. Jakarta.

Witanto D.Y. 2006. Hukum Adat Laut Sabang, Kearifan-kearifan yang Terlupakan. Yayasan Pemberdayaan Masyarakat Daerah Aceh. Banda Aceh. 